\title{
Hucksters of the "Postcolonial Business" in Search of Academic Respectability: Reflections on Contemporary Pseudo Anti-Racism in France
}

\section{Pierre-André Taguieff}

Over the past five decades, anti-racism institutionalized itself within all democratic nations. Yet the movement also turned against itself by intellectualizing and politicizing itself among minorities actively engaged in a "radical critique" of dominations of class, gender, and race. From the 1970s onward, these tendencies increased, giving rise, in the United States and then in many Western democracies, to "political correctness" as a form of policing of ordinary and expert language, as well as of political opinions and beliefs. It is within this framework that the reversal of antiracism occurred, based on two correlative operations: (1) The proliferation of identity postures led to a tendency of monopolizing the fight against racism according to the principle "to each group identity its 'racism' and its 'anti-racism,'" thereby fueling competition between self-victimized groups. (2) In parallel, the racialization of models of intelligibility of the social adorned the confused notion of "race" with explanatory value in

* I would like to thank Jean-Luc Bonniol, Jean-François Braunstein, Emmanuel Debono, Annick Duraffour, Nathalie Heinich, Laurent Loty, Céline Masson, Isabelle de Mecquenem, Dominique Schnapper, and Véronique Taquin for their remarks and suggestions. A very short version of this text was published on the website of $L$ 'Express on December 26, 2019, and co-signed by myself, Laurent Bouvet, Nathalie Heinich, Isabelle de Mecquenem, Dominique Schnapper, and Véronique Taquin. Translated by Pierre Schwarzer.

This is an open access article under the terms of the Creative Commons AttributionNoDerivatives 4.0 International (CC BY-ND 4.0) license. To view a copy of this license, visit https://creativecommons.org/licenses/by-nd/4.0. English translation (C) 2020 The TelosPaul Piccone Institute, http://www.telosinstitute.net. 
the social sciences, while the word "race" is flown like a flag by activists of this or that "racial community." It is in the name of this equivocal "anti-racism," with its many competing and contradictory meanings, that a racialist worldview is thus being recast.

Since the 1990s, this ideological corruption of anti-racism has been fed mainly by publications from various political-intellectual movements commonly subsumed without rigor under the banners of "postcolonialism" or "decolonialism." The main actors of these currents with indistinct contours are to be found in the circles of the far-left intelligentsia, that is, communist, third-worldist, radical feminist, and identity groups defining themselves on ethno-racial grounds and presenting themselves as "dominated," "racialized," "victims," or "heirs of the victims" (of slavery, colonialism). This is the politico-intellectual field in which contemporary pseudo anti-racism has arisen. In The Plague, Albert Camus makes his character Jean Tarrou say: "I'd come to realize that all our troubles spring from our failure to use plain, clear-cut language." Clarifying the language obscured by extremist ideologues and activists on the intersecting issues of "race," racism, and anti-racism is, to begin with, the thankless task of analyzing their textual productions, their real objectives and interests, and their cultural and political strategies.

\section{Deconstruction, De-westernization}

By the expression "postcolonial studies," we mean a heterogeneous set of publications by authors originally belonging to various disciplines (comparative literature, history, political science, etc.) who have little in common other than their founding fathers and their prophets (Frantz Fanon, Aimé Césaire, then Edward W. Said, Homi K. Bhabha, and Gayatri Chakravorty Spivak). ${ }^{2}$ Their main concern is the legacy of colonialismembodiment of a diabolical causality - and their hypercritical stance to-

1. Albert Camus, The Plague, trans. Stuart Gilbert (New York: Vintage Books, 1991), p. 161.

2. Edward W. Said, Orientalism (New York: Vintage Books, 1979; new ed., London: Penguin Classics, 2003); Said, Culture and Imperialism (New York: Vintage Books, 1993); Homi K. Bhabha, The Location of Culture (London: Routledge, 1994); Ranajit Guha and Gayatri Chakravorty Spivak, eds., Selected Subaltern Studies (New York: Oxford Univ. Press, 1988); Gayatri Chakravorty Spivak, The Post-Colonial Critic: Interviews, Strategies, Dialogues, ed. Sarah Harasym (New York: Routledge, 1990); Spivak, A Critique of Postcolonial Reason: Toward a History of the Vanishing Present (Cambridge, MA: Harvard Univ. Press, 1999). 
ward the West, supposedly inherently colonialist, racist, and imperialist. Their watchword is to deconstruct Western humanism, rationalism, and universalism, supposedly masking a criminal imperialism peculiar to the West. This is nothing new, at least for those who have read Friedrich Nietzsche, Theodor W. Adorno, Max Horkheimer, and Jacques Derrida, among many other Western thinkers. The only novelty is that the reasons for this deconstructionist critique are reformulated in the rhetoric of American political correctness.

The indictment of Europe is the ideological presupposition of those recognizing themselves as part of the field of postcolonial studies. ${ }^{3}$ They all take up, with various inflections, this proposition of the communist poet and politician Aimé Césaire, found at the beginning of his Discourse on Colonialism, published in 1950: "What is serious is that 'Europe' is morally, spiritually indefensible." ${ }^{4}$ The reduction of Europe to colonialism, itself denounced as the crime of crimes - a synthesis of all the figures of evil: capitalism, imperialism, racism-illustrates a double operation of essentialization and demonization. The pathologizing follows: Europe is fantasized as a power of defilement and contamination, affecting mentalities and discourses. This is to attribute to Europeans an ontological guilt, calling for endless atonement on their part. This Europe denounced as predatory is defined as a civilization (techno-scientific, capitalist, imperialist, etc.) and as a set of populations characterized by cultural, ethnic, and racial traits, among which skin color holds the central place. Therefore, the designated enemy is the "white" society, the "white" man, the "white" civilization. Driven out the front door of color-blind anti-racism, racial thought is returning through the academic window opened by postcolonial studies.

This global and essentialist criminalization of Europe and/or the West, the embodiment of "domination" - a magic word of polemical use sufficing to delegitimize the relation or process thus named ${ }^{5}$ - derives from a boundless ressentiment that translates into a litany of imprecations, calls for repentance, and demands for reparations, which may take the

3. Yves Charles Zarka, "Le postcolonialisme ou le crime inexpiable de l'Occident," Cités 72, no. 4 (2017): 3-8. [Translator's note: all untranslated works quoted directly in the text have been translated along with the article.]

4. Aimé Césaire, Discourse on Colonialism, trans. Joan Pinkham (New York: Monthly Review Press, 1972).

5. Cf. Hélène L'Heuillet, "Les études postcoloniales, une nouvelle théorie de la domination?," Cités 72, no. 4 (2017): 41-52. 
form of affirmative action policies, long implemented on U.S. university campuses. These authors, claiming postcolonialism or decolonialism for themselves, share a minimum agenda: the de-Westernization of the gaze. As for their political project, it remains undefined, lost in the sands of moralizing literary utopias, focused on the goal of a salvatory rupture.

\section{Origins, Tendencies, and Aims of Postcolonialism}

Postcolonial studies as a discipline developed mainly in the United States during the 1980s and 1990s, ${ }^{6}$ before being imported into France at the end of the 1990s and in the 2000s. ${ }^{7}$ However, the role of the British pioneers of cultural studies, such as Stuart Hall (of Jamaican origin) and Paul Gilroy (born in London to a mixed Anglo-Guyanese couple), ${ }^{8}$ as well as that of the anthropologist Arjun Appadurai, ${ }^{9}$ born in Bombay, just like Homi K. Bhabha, who like Appadurai built his career in the United States, should be highlighted as precursors or inspirations. The term "postcolonialism" is equivocal: it means both "after" and "against" colonialism in its derivative forms (the "post" then means "neo"), but also "beyond," as it is a question of breaking with the vision of an ameliorating linear evolution (on the model of the progressive schema). Moreover, adding to the confusion, it at once "designates a process of analysis, a political project, a historical

6. Bill Ashcroft, Gareth Griffiths, and Helen Tiffin, eds., Post-Colonial Studies: The Key Concepts, 2nd ed. (London and New York: Routledge, 2007); Robert J. C. Young, Postcolonialism: An Historical Introduction (Oxford: Blackwell, 2001); Young, Postcolonialism: A Very Short Introduction (Oxford and New York: Oxford Univ. Press, 2003); Epifanio San Juan, Jr., "Politique des Cultural Studies contemporaines," French trans. Soledad Navascues, L'Homme et la Société 149, no. 3 (2003): 105-24; Neil Lazarus, ed., Cambridge Companion to Postcolonial Literary Studies (Cambridge: Cambridge Univ. Press, 2004).

7. It is especially from 2005 onward that the import of postcolonial studies became apparent in France. Cf. Marie-Claude Smouts, ed., La Situation postcoloniale: Les postcolonial studies dans le débat français (Paris: Presses de Sciences Po, 2007); Émilienne Baneth-Nouailhetas, "Énigmes postcoloniales: des disciplines aux institutions," Littérature 154, no. 2 (2009): 24-35; Capucine Boidin, "Études décoloniales et postcoloniales dans les débats français," Cahiers des Amériques latines 62 (2010): 129-40.

8. Stuart Hall, Identités et cultures: Politiques des cultural studies, new exp. ed., trans. Christophe Jaquet (Paris: Éditions Amsterdam, 2008) [trans. note: this compiled edition of Hall's writings is only available in French]; Paul Gilroy, The Black Atlantic (New York: Verso Books, 1993). Cf. Jim Cohen and Jade Lindgaard, "De 1'Atlantique noir à la mélancolie postcoloniale: Entretien avec Paul Gilroy," Mouvements 51, no. 3 (2007): 90-101.

9. Arjun Appadurai, Modernity at Large: Cultural Dimensions of Globalization (Minneapolis: Univ. of Minnesota Press, 1996). 
periodization." "It can therefore be used in all kinds of ways and cover the most diverse goods. In the fourth edition (1996) of her Dictionary of Race and Ethnic Relations, Ellis Cashmore notes that the term "postcolonial" began to become popular at the same time as the term "Third World" was considered obsolete. ${ }^{11}$ The takeover has been both political and academic.

If the field is fashionable in some extreme left-wing intellectual circles, it is precisely because of its conceptual vagueness and polemical sense. Indeed, it connotes a radical cultural critique of the great modern Eurocentric narrative structured by the idea of progress, ${ }^{12}$ as well as a project of total rupture with the Western world order - defined by its hard core: capitalism-imperialism - a project likely to seduce the orphans of communism. Like other plastic terms such as "populism" or "progressivism," it functions above all as a label, attractive or repulsive. The semantic indeterminacy of the word "postcolonial" is a condition for its excessive use in the political jargon of intellectuals and for endless discussions about its "true," indeed elusive, meaning.

This conceptual vagueness in no way prevents the promoters of postcolonial studies from speaking of "postcolonial theory" as if it existed or could exist. For example, here are two French importers of the so-called "theory," believing they could dismiss criticism with a dubious argument consisting of inferring legitimacy from a fact:

Postcolonial theory, although it remains strongly controversial in French academia, is now part of the social sciences in most countries with dynamic research, from the United States to Great Britain, from Brazil to India, from Germany to the Nordic countries, from African universities to South American universities. It is a fact. ${ }^{13}$

Need we recall that not so long ago, Marxism was taught as an economic "theory" or a "science of history" in many universities in Europe and elsewhere? This "fact" in no way proved that Marxism was a consistent

10. Danilo Martuccelli, "Pour et contre le postcolonialisme," Cités 72, no. 4 (2017): 25.

11. Ellis Cashmore, "Postcolonial," in Ellis Cashmore et al., Dictionary of Race and Ethnic Relations, 4th ed. (London and New York: Routledge, 1996), p. 285.

12. Appadurai is very clear in this matter, without hiding his sources, among which many are French: "Foucault's searing critique of Western humanism and its hidden epistemologies has made it difficult to retain much faith in the idea of progress in its many old and new manifestations" (Appadurai, Modernity at Large, p. 52).

13. Nicolas Bancel and Pascal Blanchard, "Un postcolonialisme à la française?," Cités 72, no. 4 (2017): 53. 
"theory" or a science. In many respects, postcolonialism has replaced Marxism-Leninism in intellectual circles. The challenge to the Eurocentric ("white," "imperialist") social sciences has replaced that of "bourgeois science," while "postcolonial theory" or "decolonial theory"14 has replaced "proletarian science." One can also see the intellectuals engaged in postcolonialism as the heirs of the Third World movement, many of whose leading figures, especially in the Arab world, were Marxists. ${ }^{15}$

Finally, it should be remembered that the founders of subaltern studies, ${ }^{16}$ a political-intellectual movement born in India at the beginning of the 1980s (Gayatri Spivak, Ashis Nandy, Partha Chatterjee, Gyan Prakash, Dipesh Chakrabarty, et al. ${ }^{17}$ ), whose influence was decisive on the Anglo-Saxon ideologues of postcolonialism and decolonialism, were as much readers of Marx and Gramsci as of Foucault or Derrida. They saw, through the lens of the Maoist vision of the revolutionary role of

14. For the Latin American usage of the term "decolonial," starting in 1998, see Ramón Grosfoguel et al., Unsettling Postcoloniality: Decoloniality, Transmodernity and Border Thinking (Durham, NC: Duke Univ. Press, 2007); Claude Bourguignon-Rougier, Philippe Colin, and Ramón Grosfoguel, eds., Penser l'envers obscur de la modernité: Une anthologie de la pensée décoloniale latino-américaine (Limoges: Presses universitaires de Limoges, 2014); Walter D. Mignolo, The Darker Side of Western Modernity: Global Futures, Decolonial Options (Durham, NC: Duke Univ. Press, 2011).

15. Emmanuelle Sibeud, "Des 'sciences coloniales' au questionnement postcolonial: La décolonisation invisible?," Revue d'histoire des sciences humaines 24, no. 1 (2011): 3-16; Thomas Brisson, Décentrer l'Occident: Les intellectuels postcoloniaux chinois, arabes et indiens, et la critique de la modernité (Paris: La Découverte, 2018), pp. 191-214.

16. For a broad overview, see: Mamadiou Diouf, ed., L'historiographie indienne en débat: Colonialisme, nationalisme et sociétés postcoloniales (Paris and Amsterdam, Éditions Karthala \& Sephis, 1999); Jacques Pouchepadass, "Les Subaltern Studies ou la critique postcoloniale de la modernité," L'Homme: Revue française d'anthropologie 156, (2000): 161-86; Isabelle Merle, "Les Subaltern Studies: Retour sur les principes fondateurs d'un projet historiographique de l'Inde coloniale," Genèses 56, no. 3 (2004): 131-47; Anne Castaing, "Subaltern Studies: De la provincialisation de l'Europe au langage de la différence," in Matérialismes, culture et communication, bk. 2, Cultural Studies, théories féministes et décoloniales (2016), https://hal.archives-ouvertes.fr/hal-01988087/document.

17. Ashis Nandy, The Intimate Enemy: Loss and Recovery of Self under Colonialism (Delhi: Oxford Univ. Press, 1983); Gayatri Chakravorty Spivak, "Can the Subaltern Speak?," in Cary Nelson and Larry Grossberg, eds., Marxism and the Interpretation of Culture (Chicago: Univ. of Illinois Press, 1988); Partha Chatterjee, The Nation and Its Fragments: Colonial and Postcolonial Histories (Princeton, NJ: Princeton Univ. Press, 1993); Gyan Prakash, ed., After Colonialism: Imperial Histories and Postcolonial Displacements (Princeton, NJ: Princeton Univ. Press, 1995); Dipesh Chakrabarty, Provincializing Europe: Postcolonial Thought and Historical Difference (Princeton, NJ: Princeton Univ. Press, 2008). 
peasants, and more generally of the experience and culture of the "dominated" groups resisting the "dominant" party (Western imperialists or westernized Indian elites), a source of inspiration in the "daily forms of resistance" of these groups. Their double objective was to deconstruct the great "Eurocentric" narrative of modernization and to confer legitimacy on the forms of life, thought, and discourse of the "subalterns." "18

This exotic culturalist populism, violently anti-universalist, has been severely criticized "from the left" by the American Marxist sociologist Vivek Chibber. ${ }^{19}$ Finding themselves in a situation of competition within the extreme left or "radical left" intelligentsia - that is, the left opposed to the social democratic path - with postcolonialist and decolonialist "theorists," Marxists who resist the siren call of the latter are well placed to glimpse the explanatory illusions that guide their rivals in the transnational academic field. Let us say, for the sake of simplicity, that the adage "in the light of postcolonialism" tends to replace the old Stalinist formula "in the light of Marxism," driven by political-intellectual fashion.

The intellectualized anti-capitalism of the Marxists had its key to history: class struggle. The racialized anti-capitalism of the postcolonialists/ decolonialists forged a new key to history, applicable to modern and contemporary times, a key endowed with an explanatory omnipotence no less imaginary: racialized imperialism attributed to the "dominators," equated with Europeans, Westerners, or "whites." Racialist demonology drives out classist demonology. The ironic paradox of postcolonialism or decolonialism is that its ideologues are making a racialist reinterpretation of the radical critique of capitalism and imperialism using intellectual tools borrowed from the "white world," a world they spit out, accusing it of being the cause of all the misfortunes of the rest of humanity.

\section{Racializing in the Name of Anti-Racism}

All theorists-ideologists of postcolonialism postulate that in postcolonial societies, the legacy of colonialism, an expression of "white domination," is both alive and structuring. They believe it at work in the dominant social order, mentalities, and discourses. Hence the call to deconstruct social

18. Jacques Pouchepadass, "Que reste-t-il des Subaltern Studies?," Critique international 24, no. 3 (2004): 67-69.

19. Vivek Chibber, "L'universalisme, une arme pour la gauche," Le Monde diplomatique, May 2014, pp. 22-23. From the same Marxist sociologist, see Postcolonial Theory and the Spectre of Capital (New York: Verso, 2013). 
representations, beliefs, and stereotypes making up this legacy, and even, for the most radical ones, the entire social-racial order, supposedly intrinsically unequal and discriminatory. But this anti-racist orientation coexists with a propensity to view all social and political problems in ethno-racial terms, namely, on the basis of the binary categorization of "white-black" or "white vs. others," as well as on the grounds of the opposition between dominant and dominated. As a result, racial identities are brought to the fore, marginalizing all other aspects of social and cultural life. This is postulating something akin to a heredity of conditions.

Postcolonial studies thus form a nebula rather than a school of thought or field of research defined by its methodology, specific conceptuality, and body of hypotheses. The driving passion of their "theorists" is ressentiment against Europe, which they want-in the best of cases - to "provincialize" (to use the expression of the converted Marxist historian Dipesh Chakrabarty ${ }^{20}$ ), forgetting that the intellectual tools of their deconstructive criticism come from it-from Marx and Gramsci to Michel Foucault, Gilles Deleuze, and Jacques Derrida, via Heidegger and Lacan. ${ }^{21}$ For these "theorists" do indeed flirt with philosophy, despite them mostly having no proper philosophical training - teachers of English and comparative literature are in the majority in their ranks. ${ }^{22}$ Most of them only know Plato, Descartes, Hegel, Nietzsche, or Heidegger through the writings of Foucault, Deleuze, Lyotard, or Derrida, commented on or translated in the language departments of American universities - the philosophy departments dealing mainly with analytical and moral philosophy. Their Marx is that of Gramsci or Althusser. In most cases-Appadurai and Chakrabarty being notable exceptions - we find ourselves in the presence

20. Chakrabarty, Provincializing Europe, esp. the preface.

21. Let us add to the pantheon the name of Louis Althusser, as well as the less-cited ones of Jean-François Lyotard, Félix Guattari, and Jean Baudrillard. For a critical examination, see Jean-Loup Amselle, L'Occident décroché: Enquête sur les postcolonialismes (Paris: Stock, 2008).

22. Robert J. C. Young, for instance, who is the editor of Interventions: International Journal of Postcolonial Studies, is a professor of English and comparative literature. After rallying the "post-structuralist" current in the 1980s, he embraced the cause of postcolonial studies. Homi Bhabha is also a scholar of English literature, which leads him to speak of everything with authority and "radicality." Like Edward Said, Gayatri Chakravorty Spivak has taught comparative literature. With regard to Walter D. Mignolo, he has taught semiotics and literary theory before becoming a decolonial "theorist." Let us underscore that all of them claim to be "theorists." 
of second-hand philosophical culture and intellectual work..$^{23}$ It is better to read the continental philosophers in their original texts than in their subalternist, postcolonial, or decolonial copies.

From the selective corpus that they have assembled for themselves, the "theorists" of postcolonialism derive a few cryptic formulas to embellish their denunciatory, sloganizing discourse. The result is the production of texts in which obscurity flirts with theoretical cuisine, heavily paraphrasing Foucault or Derrida, sometimes imitating Lacan-Spivak's texts are emblematic in this respect. Let us take an example, from the last chapter of Robert J. C. Young's 2001 book on postcolonialism, in which the "theorist" writes about Derrida, who would have developed "deconstruction as a procedure of intellectual and cultural decolonization in the heart of the metropolis" (sic):

The surgical operation of deconstruction was always directed at the identity of the ontological violence that sustains the western metaphysical and ideological systems with the force and actual violence that has sustained the western nations in their colonial and imperial policies, a structural relation of power that had to be teased apart if it was ever to be overturned. ${ }^{24}$

What is called "postcolonial thought" is thus reduced to a rhetorical mush made of borrowings from a handful of famous authors, considered "postmodern" and then subsumed under the hyped and deceptive label of "French Theory," 25 to which Fanon and Said are added. It is on top of their names that texts are written, claiming to be "radical" (theoretically, politically, etc.), in a pedantic jargon followed by hollow formulas on the theme of violence in the West- some are literary as well as scholarly, ${ }^{26}$ some are militant, others are polemical. The relativist thesis that the idea

23. Let us highlight that Dipesh Chakrabarty, Marxist historian reconverted to postcolonialism, does not rely on any secondary literature- he is free from any desire of vengeance often encountered in postcolonial ideologues: "For at the end of European imperialism, European thought is a gift to us all. We can talk of provincializing it only in an anticolonial spirit of gratitude" (Chakrabarty, Provincializing Europe, p. 255).

24. Young, Postcolonialism: An Historical Introduction, p. 416.

25. On this unpalatable "theoretical" cocktail, see Sylvère Lotringer and Sande Cohen, eds., French Theory in America (New York: Routledge, 2001); François Cusset, French Theory: Foucault, Derrida, Deleuze \& Cie et les mutations de la vie intellectuelle aux États-Unis (Paris: La Découverte, 2003).

26. Achille Mbembe, Politiques de l'inimitié (Paris: La Découverte, 2016). 
of a universal rationality is a Western sham is the main one. ${ }^{27}$ We can also cite the frequently snappish claim that racism is solely ${ }^{28}$ an invention of the transatlantic slave trade and modern European colonialism, and that it is still present, albeit hidden, in modern democracies. Achille Mbembe, for example, writes: "Democracy, plantation, and colonial empire are objectively part of the same historical matrix. This original and structuring fact is at the heart of any historical understanding of the violence of the contemporary world order." ${ }^{29}$ It could not be better stated, in para-philosophical language, that "the white man" is intrinsically guilty.

Alan Sokal's analysis of Franco-American "intellectual impostures" should be extended to this mixture of pseudo-scientific approaches, ${ }^{30}$ pompous "deconstructions," and "radical" postures. New precious theorist clowns, addicted to textual games of adding "trans-" 31 and "post-" to concepts, practice an inflationary generalization for an ever more radical criticism, turning themselves into activists or political prophets. This is how the theorist of a "radical anti-systemic politics," Ramón Grosfoguel, ${ }^{32}$ celebrating the decolonial studies of which he is one of the great masters, calls for "decolonizing postcolonial studies." 33 In Provincializing Europe,

27. Cf., for instance, Achille Mbembe, "Qu'est-ce que la pensée postcoloniale?," interview, Esprit, December 2006, pp. 117-33 ; Mbembe, Critique of Black Reason, trans. Laurent Dubois (Durham, NC: Duke Univ. Press, 2017).

28. Cf. Walter D. Mignolo, The Idea of Latin America (Malden, MA: Blackwell, 2005).

29. Mbembe, Politiques de l'inimitié, p. 37.

30. Cf. Alan Sokal and Jean Bricmont, Fashionable Nonsense (London: Picador, 1998); Alan Sokal, Beyond the Hoax: Science, Philosophy and Culture (Oxford and New York: Oxford Univ. Press, 2008).

31. Cf. Bruno Chaouat, L'Homme trans: Variations sur un préfixe (Paris: Éditions Léo Scheer, 2019).

32. Ramón Grosfoguel (born in 1956), of Puerto Rican descent, has been an associate professor in Berkeley's Department of Ethnic Studies, where he taught in the field of Chicano/Latino studies. His "radicality" is praised among others in indigenist and decolonial circles in France. The spokeswoman of the Parti des Indigènes de la République (PIR), Houria Bouteldja, for instance, thanks him in the preface of her racialist-revolutionary book Les Blancs, les Juifs et nous: Vers une politique de l'amour révolutionnaire (Paris: La Fabrique éditions, 2016), p. 9, and calls him "my brother," labeling him one of these "radical militants acting out of idealism, without overthinking the consequences of their actions." She thanks him for "his faith, his steadfast commitment, and his deep friendship." It is unsurprising that he opened the PIR's conference "For a Decolonial Reading of the Shoah," January 13, 2012, http://indigenes-republique.fr/pour-une-lecture-decoloniale-de-la-shoah/.

33. Ramón Grosfoguel, "From Postcolonial Studies to Decolonial Studies: Decolonizing Postcolonial Studies: A Preface," Review (Fernand Braudel Center) 29, no. 2 (2006): $141-42$. 
Chakrabarty defines his project as a historian as "a broader effort to situate the question of subaltern history within a postcolonial critique of modernity and of history itself." ${ }^{\prime 34}$ And he emphasizes the importance he attaches to the historian's activist engagement: "Writing subaltern history, that is, documenting resistance to oppression and exploitation, must be part of a larger effort to make the world more socially just." 35 Postcolonialism at the service of the Revolution? This would be a way of decolonizing Marxism.

Let's be clear. It is possible to study the polymorphous legacies of slavery and colonization without bluster, without victim mythology or Manichaeism, without any desire for revenge or resentment, and it is even necessary to engage in such work, in accordance with the standards of scientific research. ${ }^{36}$ But this is precisely what decolonial or indigenist ideologues and their postcolonial cousins do not do, the latter in spite of their efforts to gain academic respectability.

All of them, academics, activists, and ideological entrepreneurs claiming to be postcolonial, postulate that "Western" or "white" domination, through colonization or colonial imperialism, is the new key to history. This assumes that the West, a repulsive civilizational figure, was the only actor in history, the grim actor in a criminal history, and sets up as a fundamental intellectual prism the Manichaean opposition between "them" and "us," between "Europeans" (colonialists, imperialists, racists) and others, between "white males" and others (racialized males, women, etc.). As grounding evidence, they also spread the view that the engine of history is the struggle of races and genders. For some, "race" explains everything. It is, of course, a "social construction," but what is not, in their view, a "social construction"?

34. Chakrabarty, Provincializing Europe, p. 72.

35. Ibid.

36. Cf., for instance, Patrick Weil and Stéphane Dufoix, eds., L'esclavage, la colonisation, et après.... France, États-Unis, Grande-Bretagne (Paris: PUF, 2005); Alexis Spire, Étrangers à la carte: L'administration de l'immigration en France (1945-1975) (Paris: Grasset, 2005); Romain Bertrand, Mémoires d'empire: La controverse autour du "fait colonial" (Clamecy: Éditions du Croquant, 2006); Emmanuelle Saada, Les enfants de la colonie: Les métis de l'Empire français entre sujétion et citoyenneté (Paris: La Découverte, 2007). See also the works of the anthropologist Jean-Luc Bonniol, La couleur comme maléfice: Une illustration créole de la généalogie des "Blancs" et des "Noirs" (Paris: Albin Michel, 1992); Bonniol, "Comment transmettre le souvenir de l'esclavage? Excès de mémoire, exigence d'histoire,” Cités 25, no. 1 (2006): 181-85. 
This hateful hesperophobia, ${ }^{37}$ this hatred of the West theorized by the followers of postcolonialism and decolonialism, feeds the anti-white racism spread by active minorities made up of imaginary "racialized" people, based on the model of the Indigenes de la République, denouncing a chimerical "state racism" and a "systemic racism" existing only in their phantasms ${ }^{38}$ Hence their accusations against those who dare criticize them, reduced to their supposed origins (as "non-racialized" and "dominant," even "white") and thus suspected of "methodological nationalism." These followers of a racialized neo-Marxism and neo-anti-racism are also declared enemies of the modern nation-state, the invention of the European "imperialists" and "racists."

\section{Acquiring an Academic Respectability in France: The Postcolonial Business}

It would appear that a further step toward the institutionalization of postcolonial studies has unfortunately been taken in France, despite the strong criticisms it has provoked, even though it is being monopolized by the ACHAC (Association Connaissance de l'Histoire de l'Afrique Contemporaine), created in 1989 and bringing together real or supposed researchers, political activists, journalists, and ideological or cultural entrepreneurs, who claim to work "on colonial and postcolonial representations and imaginaries." ACHAC's leaders (Nicolas Bancel, Pascal Blanchard, Gilles Boëtsch, Éric Deroo, Sandrine Lemaire) published their manifesto book Zoos humains XIXe et XXe siècles: De la Vénus hottentote aux reality shows in 2002, with the publisher La Découverte. They thus claim to contribute to the "understanding of the passage from a scientific racism to a colonial and popular racism diffused in the West." A vast agenda!

The historian of anthropology Claude Blanckaert, one of the head researchers at the CNRS, has devoted a long critical note to this collective work, which is intended to give a scholarly label to the product "human zoos," launched a few years earlier. ${ }^{39} \mathrm{He}$ considers the scientific value of

37. The neologism of "hesperophobia," introduced by the historian Robert Conquest, has been used by John Derbyshire in "Hesperophobia: On Blaming the Jews," National Review Online, September 13, 2001.

38. Cf. "Le 'décolonialisme,' une stratégie hégémonique: L'appel de 80 intellectuels," Le Point, November 28, 2018, https://www.lepoint.fr/politique/le-decolonialisme-unestrategie-hegemonique-1-appel-de-80-intellectuels-28-11-2018-2275104_20.php.

39. For instance: Nicolas Bancel, Pascal Blanchard, and Sandrine Lemaire, "Ces zoos humains de la République coloniale," Le Monde diplomatique, August 2000, pp. 16-17; 
the book to be close to zero, the "human zoo" operation being reduced to the creation of a new publishing market or more generally a new media fad. He concludes his ruthless analysis as follows:

It is clear that the history of science is only a pretext, but there is nothing to indicate that the social history, the very history of mentalities, finds itself better addressed in the book. Between denunciation and sleight of hand, the promoters of the "human zoo" project have not been able to identify, or problematize, their object of investigation.... In its form, and sometimes in its content, the book Zoos humains does not escape the commercial hyperbole and sensationalism of the shows it denounces. We can bet that the book will be a huge commercial success. The second volume has already been announced! ${ }^{40}$

The main lesson given by the doctors of French postcolonialism is the following: "It is essential to study the view of the Other as it manifested itself in colonial times in order to understand the prejudices still at work today. Human zoos are a striking example of this." ${ }^{41}$ Self-justification here involves an oversimplification of the problem of otherness: the "view of the Other" of Europeans is far from being reduced to that of the spectator of human zoos, which cannot be taken as an exemplary illustration either. It is indeed an ideological and pedagogical offer that is predominantly "antiracist," but which, surreptitiously, plays on the attractiveness of the racial spectacle.

An instrument of self-promotion for its members, ACHAC is also backed by a company of which Pascal Blanchard is the co-director, the communication agency Les Bâtisseurs de Mémoire [The Builders of Memory] ("Council, communication, history"), offering to "promote the historical, advertorial, and financial past of major brands," whose productions and lucrative purposes are clearly questionable in the academic world. ${ }^{42}$ These commercial uses of history should be totally foreign to

Bancel, Blanchard, and Lemaire, "Des zoos humains aux apothéoses coloniales: L'ère de l'exhibition de l'Autre," Africultures 43 (2001): 48-57.

40. Claude Blanckaert, "Spectacles ethniques et culture de masse au temps des colonies," Revue d'histoire des sciences humaines 7, no. 2 (2002): 230-31.

41. Bancel, Blanchard, and Lemaire, "Des zoos humains aux apothéoses coloniales," p. 48 .

42. For a proper analysis, see Camille Trabendi, "Pascal Blanchard en 'Free Lance Researcher," Agone, May 18, 2010, http://blog.agone.org/post/2010/05/18/PostcolonialBusiness-2; Sylvain Laurens, "Les vertus curatives de la boue: Lettre ouverte à Pascal 
the world of research. How then should we interpret the support given by the president of the CNRS, Antoine Petit, to the latest publication by Blanchard's friends, Sexualités, identités et corps colonisés (CNRS Éditions, November 2019, with a foreword by Petit), shortly before a symposium was organized by ACHAC in Paris on December 3, 2019, to promote the launch of a book that, apart from a few solid studies by real historians, is only a mirror of the decolonial cultural leftism rampant in certain intellectual circles and some university campuses? Mimicking postcolonial rhetoric in his foreword, including inclusive writing, the enthusiastic CEO of the CNRS concludes by summarizing with sympathy the central thesis of the ACHAC book, which he warmly recommends to the public:

Race becomes the new reading grid of the world on which the gender grid is integrated, and which is articulated along with the male/female hierarchy: in the colonies, the smallest among the "whites," on the social scale, will always be larger than any colonized person, especially if that person is a woman.... The sharing of these works, which must be read by all, constitutes [sic] an essential document of knowledge on pasts that move, shock and, in any case, challenge. ${ }^{43}$

Petit was to open the December 3 symposium in the company of Olivier Faron, general administrator of the CNAM, who publicly declared (as Petit was otherwise occupied) that this symposium was a "first step" toward the creation, in France, of chairs of postcolonial studies, which "our country very much lacks." 44 The merchants of postcolonialism can thus believe they are on the way to winning the battle for institutional recognition, or even consecration.

\section{Postcolonialism, Indigenism, Decolonialism: Interferences and Cronyisms}

Since their manifesto book La fracture coloniale (2005), French importers of postcolonial studies claim to decipher contemporary French society

Blanchard et ses partenaires," Agone, May 18, 2010, http://blog.agone.org/post/2010/05/18/ Postcolonial-Business-1.

43. Antoine Petit, foreword to Sexualités, Identités et corps colonisés: XVe siècle$X X I^{e}$ siècle, ed. Gilles Boëtsch et al. (Paris: CNRS Éditions, 2019), p. 10.

44. Cf. Amandine Hirou, "Les obsédés de la race noyautent le CNRS," L'Express, December 24, 2019, pp. 55-57. 
"through the prism of colonial heritage." They only decipher their own fantasies, hauntings, or obsessions, which presuppose the eternal return of the past into the present. According to them, everything can be explained by survivals and resurgences. There would be no end, for example, to returning to the 1930 s, to replay this or that repulsive period of the past. "To understand the crises of the present," they assert, is to suppose that "the thirties are back" (the title of a book ${ }^{45}$ co-written by Blanchard and Yvan Gastaut, ${ }^{46}$ published in 2014 by Flammarion). This is how these simple minds believe they can analyze the complex dynamics of contemporary nationalism and populism. Dogmatic and magical thinking, intellectual laziness, and no scientific approach.

In 2006, Blanchard and Nicolas Bancel published under their direction a collective work entitled Culture post-coloniale 1961-2006: Traces et mémoires coloniales en France. In the contribution of the indigenists Saïd Bouamama and Pierre Tévanian ${ }^{47}$ on "postcolonial racism," we find a recourse to the most summary culturalist model to explain the existence of the latter, at the same time as a denunciation of the culturalist justifica-

45. Renaud Dély, Pascal Blanchard, Claude Askolovitch, and Yvan Gastaut, Les années 30 sont de retour: Petite leçon d'histoire pour comprendre les crises du présent (Paris: Flammarion, 2014).

46. Yvan Gastaut, a historian specialized in the study of soccer, has published, among others, Le métissage par le foot: L'intégration, mais jusqu'où?, prefaced by the soccer player Lilian Thuram (Paris: Éditions Autrement, 2008). In his preface, Thuram sums up the mixophiliac and mobilist credo of this "anti-racist" environment: "Every culture is a blend made of multiple contributions grounded in the same entity in perpetual evolution. This is not news: mobility has been a feature of Mankind since its advent.... I believe one must now realize we are all immigrants and mixity is a process no one can stop." The utopia of universal hybridization as the establishment of a post-racist world is indeed one of the political chimeras one can find in the writings of post- and decolonial scholars.

47. The far-left militant Pierre Tévanian, calling himself "anti-racist," has been a part of the MRAP [Movement against racism and for the friendship of peoples, a French NGO] and the Dieudonné movement, and has co-signed the call of the Indigènes de la République (2005). The left-wing rapper Saïd Bouamama, presenting himself as an anti-colonial, antiracist, and anti-capitalist activist, has been one of the founders of the movement of the Indigènes de la République. This CGT Trade Unionist of Algerian descent has professionalized the hatred of France, deemed "racist, colonialist, discriminatory, and unequal," as well as the fight against "Islamophobia," in his eyes the main form of "racism" existing in France. He co-authored a violent Francophobic pamphlet entitled Nique la France: Devoir d'insolence [Fuck France: The Duty of Disrespect] (Roubaix: Darna Éditions, 2010). Cf. Gilles Kepel, Passion française: Les voix des cites (Paris: Gallimard, 2014), pp. 154, 252 53; Pierre-André Taguieff, Une France antijuive?: Regards sur la nouvelle configuration judéophobe (Paris: CNRS Éditions, 2015), pp. 31-32. 
tions of the rejection of the "other" or the "different"- the contradiction does not bother them. Postcolonial racism, they argue, "was constructed as a legitimation of colonial aggression and privilege," and was transmitted from generation to generation, both during the colonial era and after independence. It is on the basis of evidence, without the slightest sociological investigation, that Bouamama and Tévanian assert the existence of postcolonial racism:

It can hardly be denied that in contemporary French society representations of the "Black," the "immigrant," the "Muslim," the "beur," or the "beurette" continue to circulate — and to act—on a massive scale, overemphasizing a "cultural" difference ("they" are different from "us") and obscuring other differences, particularly class or "personality" differences ("they" are all the same, and "we" all share the same "national identity"). ${ }^{48}$

Everything can therefore be explained by the transmission of colonial racism: it is the persistence of prejudices and negative stereotypes formed during colonization that explains all problems linked to immigration today. Migrants are innocent no matter what they do, they are innocent by nature and culture, and they are even destined to be the victims of the racists who make up the populations of host countries. Any reaction of rejection directed at postcolonial migrants or descendants of migrants testifies to the existence of postcolonial racism, which affects the state and its policies as much as civil society.

The ideological enterprise proceeds on the issues of "Islamophobia" and the rise of extreme right-wing nationalisms, the only threats taken into account by these intellectuals and activists seeking to adapt the interpretative models and arguments of an old anti-fascism to the analysis of contemporary societies, seventy years after the disappearance of fascism. Their banner is still the same: the "colonial divide." For example, the book Vers la guerre des identités? [Toward the War of Identities], published in 2016 under the direction of Blanchard, Bancel, and Dominic Thomas, brings together texts by academics, essayists, journalists, and

48. Saïd Bouamama and Pierre Tévanian, "Peut-on parler d'un racisme post-colonial?," Culture post-coloniale 1961-2006: Traces et mémoires coloniales en France, ed. Pascal Blanchard and Nicolas Bancel (Paris: Éditions Autrement, 2006), p. 244. 
novelists who aim to shed light on the process "from the colonial divide to the ultra-national revolution [sic]." ${ }^{, 49}$

Let us open a parenthesis. It is one thing to declare, as President Macron did in Côte d'Ivoire on December 21, 2019, that colonialism "was a profound error, a fault of the Republic"; it is another to declare, as he did on February 17, 2017, on an Algerian television channel: "Colonization is part of French history. It is a crime against humanity, a true monstrosity." The first declaration is a political and moral judgment that we may not share, but which is debatable; the second is a mistaken and intolerable judgment that amounts to confounding colonization with extermination, or, more precisely, colonial racism, based on the inferiorization, domination, and exploitation of colonized peoples, and extermination or genocidal racism, whose aim is to destroy a subhumanity considered as waste. ${ }^{50}$ It is this crude polemical amalgam that decolonial ideologues and the most radical followers of postcolonialism make.

There is a continuum between academic discourses by supporters of postcolonial theory and the political positions of the indigenous or decolonialists. Many intellectuals claiming to be postcolonial are at once decolonial activists. For example, decolonial activist Françoise Vergès published several books in collaboration with Blanchard and Bancel, such as La fracture coloniale (2005), ${ }^{51}$ Ruptures postcoloniales (2010), ${ }^{52}$ and Sexe, race et colonies (2018), ${ }^{53}$ before publishing her neo-feminist pamphlet Un féminisme décolonial (2019) with a publisher specializing in

49. Pascal Blanchard, Nicolas Bancel, and Dominic Thomas, Vers la guerre des identités?: De la fracture coloniale à la révolution ultranationale (Paris: La Découverte, 2016).

50. On the fundamental distinction between a racism of exploitation and a racism of extermination, see Jeanne Hersch, "Sur la notion de race," Diogène 59 (1967): 127-28; Pierre-André Taguieff, La force du préjugé: Essai sur le racisme et ses doubles (Paris: Gallimard, 1990), pp. 163-76.

51. Pascal Blanchard, Nicolas Bancel, and Sandrine Lemaire, eds., La fracture coloniale: La société française au prisme de l'héritage colonial (Paris: La Découverte, 2005).

52. Nicolas Bancel et al., eds., Ruptures postcoloniales: Les nouveaux visages de la société française (Paris: La Découverte, 2010). In this book, the members of the postcolonial research group ACHAC blend contributions by actual, competent scholars with those by militants, activists, and ideologues in a strategy of legitimation via contiguity. While the first are supposed to legitimate the others, they may nevertheless find themselves "tarnished" by the co-presence of the latter.

53. Pascal Blanchard et al., eds., Sexe, race et colonies (Paris: Éditions La Découverte, 2018). 
radical anti-Zionism and anti-Republican indigenism. ${ }^{54}$ In this pamphlet, she postulates that, in the French Republic, "the institutions of power remain structured by racism." ${ }^{55}$ She denounces "white and imperialist feminism," "civilizational or bourgeois white feminism," "femonationalism," and "French republican coloniality," calling for the "destruction of racism, capitalism, and imperialism." 56 This accumulation of denunciations in coded language was already contained in a pamphlet published in 2012 by the same militant publisher: Félix Boggio Ewanjé-Ewanjé-Épée and Stella Magliani-Belkacem, Les féministes blanches et l'empire ${ }^{57}$ [White Feminists and the Empire], in which the "white feminists" or "hegemonic feminists" are pilloried along with the "heterosexist white republic" and "Islamophobia."

Vergès's militant text of great violence followed the publication of Les Blancs, les Juifs et nous (2016), ${ }^{58}$ written by the icon and spokesperson of the Party of the Indigènes de la République (PIR), Houria Bouteldja, who defines her identity in racial terms as follows: "I am not completely white. I am whitened. I'm here because I've been thrown up by history. I'm here because white people were in my home, and they're still there. What am I? An indigenous of the republic." ${ }^{, 59}$ In an interview given to an Algerian newspaper, posted online on May 26, 2009, the decolonial activist did not hide her total rejection of the idea of integration or assimilation and of the Western model of the nation-state: "We question the idea of the nation-state, which institutes the uniqueness of a race. Yet France wants to highlight the nation-state, along with the Christian values of white Europeans." She goes on to add the following calamity: "The nation-state is the very consecration of racism and the negation of diversity in the sense that all those who are not white, Christian, and European are excluded from citizenship. ${ }^{\circ 60}$ In an interview published in April 2006 on the theme "feminism and anti-racism," Bouteldja spoke out against "republi-

54. Françoise Vergès, Un féminisme décolonial (Paris: La Fabrique éditions, 2019).

55. Ibid., p. 28.

56. Ibid., pp. 11, 28, 32.

57. Félix Boggio Ewanjé-Ewanjé-Épée and Stella Magliani-Belkacem, Les féministes blanches et l'empire (Paris: La Fabrique éditions, 2012).

58. Bouteldja, Les Blancs, les Juifs et nous.

59. Ibid., p. 26.

60. Houria Bouteldja, "Libération pas intégration," interview, Parti des Indigènes de la République website, May 26, 2009, http://indigenes-republique.fr/un-entretien-avechouria-bouteldja/. 
can racism" and, as representative of the Indigènes de la République, violently challenged the feminist organization Ni Putes Ni Soumises (NPNS) in racialist terms: "We no longer want false representatives. At NPNS, for example, it is not they who speak; it is the whites who speak through them. On the contrary, we can't let others speak for us."61 "White people" against others: the basic oppositional structure of racist tendencies is here merely inverted. Also not to be forgotten is the following, written by the spokesperson of the PIR at the end of March 2012, after the death of the jihadist Mohammed Merah:

Mohammed Merah is me. The worst thing is that it is true. Like me, he is of Algerian origin, like me, he grew up in a neighborhood, like me, he is Muslim.... Like me, he knows he will be called an anti-Semite if he supports the colonized Palestinians, a fundamentalist if he supports the right to wear a headscarf. Mohammed Merah is me, and I am him. We are of the same origin, but above all we are of the same condition. We are postcolonial subjects. We are indigenous of the republic.... I say tonight, I am fundamentally Muslim. ${ }^{62}$

Such remarks, legitimizing the terrorist action committed by a "postcolonial subject" deemed a victim of colonial domination, did not dissuade Vergès from regularly relaying Bouteldja's publications on social networks. From 2014 to 2018, Vergès held the Global South(s) Chair at the Collège d'études mondiales, part of the Fondation Maison des sciences de l'homme (FMSH), of which Michel Wieviorka, one of the importers of political multiculturalism to France, has been the administrator since July 2009. This did not prevent the latter from launching an "International Platform on Racism and Antisemitism" in March 2019, proposing to address these phenomena "in a global manner." ${ }^{63}$ Previously, between 2007 and 2010, Vergès had worked on a project for a postcolonial museum for the twenty-first century. The decolonial activist thus presents, by accumulating the clichés of postcolonial rhetoric, the program of her chair, clearly

61. Houria Bouteldja, "Féminisme et antiracisme," interviewed by Chiara Bonfiglioli, ContreTemps 16 (2006): 93.

62. Houria Bouteldja, "Mohamed Merah et moi," Parti des Indigènes de la République website, April 6, 2012, http://indigenes-republique.fr/mohamed-merah-et-moi/.

63. "Plateforme internationale sur le racisme et l'antisémitisme," Fondation Maison des sciences de l'homme, http://www.fmsh.fr/fr/recherche/30674. The "scientific coordinator" of said platform is the journalist, editor, and "affiliated researcher" at the CANTHEL-cluster of the University of Paris 5, Régis Meyran. 
oriented toward an assumed and theorized anti-Westernism as well as a project of "denationalization" of cultural productions:

Created in September 2014, the Global South(s) Chair approaches the South(s) as spaces and temporalities that intersect and interact. The "South" is here not a geographical notion but a process that unfolds from different regimes: the coloniality of power, forms of colonization, racialization and predation, identity retrenchments, ideological configurations of an abstract universalism and counter-hegemonic strategies. This chair benefits from the multi-year support of the Ministry of National Education, that of Higher Education and Research, as well as that of the Overseas Territories.

The methodological approach is that of decolonial thinking, a "denationalization" of narratives and periodizations, a revision of cartography developed from and in relation to the West - a vision that has marginalized other routes of exchange and encounter and undervalued the dynamic creation of other centers and peripheries. Racism will be analyzed here as a problem constituting specific social relations, as structuring societies and not as a moral problem. It will examine how racializing ideology permeates culture and the arts, either by masking the effects or by exhibiting them. ${ }^{64}$

In the fall of 2018, Vergès, an activist intellectual whose resentment against "white France" is all the greater because she has never been able to secure an academic position in France-despite the support of leftist networks committed to decolonialism - said in a speech at the Parisian baragora La Colonie (decolonial typography), the mecca of decolonialism: "They [whites] will give us nothing, we will take everything away....We don't want to integrate into white France." 65 The artist Kader Attia, host of the trendy location, summed up the decolonial vision of the world perfectly: "In truth, with 'decolonial,' a whole Pandora's box has been opened because, at the end of the day, what we are dealing with is nothing more than a demand for reparation. It can no longer be denied that there is a colonial continuity between yesterday and today and that it is expressed

64. Françoise Vergès, “Global South(s)," Fondation Maison des sciences de l'homme, http://www.fmsh.fr/fr/college-chaires/24262.

65. Cited by Dounia Hadni, "Françoise Vergès, le temps décolonie," Libération, March 6, 2019, https://www.liberation.fr/debats/2019/03/06/francoise-verges-le-tempsdecolonie_1713402. 
in the psyches and institutions. ${ }^{, 66}$ In addition to being unreluctant to work with the PIR (of which she was a member in the past), Vergès is very active within the association Décoloniser les Arts [Decolonizing the Arts], created in 2015 and of which she is the president. The purpose of this militant association is, essentially, to "fight against the discrimination of minority and postcolonial populations in the performing arts and the arts," to "ensure their representation on stage," and thus contribute to "decolonizing the imagination." From this perspective, Vergès does not hesitate to denounce the "white disease." If her thunderous declarations are to be believed, the activist longs for a scuffle. This is her favorite stance. One is tempted to retort, with the necessary irony, what Albert Camus said in reply to Emmanuel d'Astier de La Vigerie: "I hate comfortable violence. I abhor those whose words go further than their deeds. ${ }^{\circ 67}$

Thus, it is with characters such as Olivier Le Cour Grandmaison or Françoise Vergès that Pascal Blanchard and his friends launched their great offensive in the media and institutions. The imposture was clear from the mid-2000s onward. However, as a result of this very concerted strategy, the enterprise succeeded, at least partly, in "enlisting the academic sphere," and it penetrated the educational institutions by hammering home the contested idea of a continuity of colonization in the social and political treatment of immigration. This is despite the dreadful effects of the "ethnicization of social relations" that have long been denounced by a specialist on Africa such as Jean-François Bayart in his critical essay on postcolonial studies, ${ }^{68}$ which attacks them for reifying or essentializing the colonial fact ${ }^{69}$ and for postulating "the mechanical, univocal, and overdetermining reproduction of the concept of the colonial,",70 thus producing a de-historicization of the approaches of the latter, turned into the object of a narrative both mythical and mystifying, in that it presupposes a hereditary vision of attitudes, beliefs, and behavior. The academic Isabelle Barbéris has de-

66. Cited by Séverine Kodjo-Grandvaux, "La colonie, quartier général de l'intelligentsia 'décoloniale," " Le Monde, October 20, 2019, https://www.lemonde.fr/afrique/article/2019/10/20/1a-colonie-quartier-general-de-1-intelligentsia-decoloniale_6016240_3212. html.

67. Albert Camus, "Deux réponses à Emmanuel d'Astier de La Vigerie," in CEuvres complètes, bk. 2 (Paris: Gallimard, 2006), p. 458 ("Première réponse").

68. Bayart, Les études postcoloniales. See also Jean-Loup Amselle, L'Occident décroché: Enquête sur les postcolonialismes (Paris: Stock, 2008).

69. Bayart, Les études postcoloniales, pp. 46-58.

70. Ibid., p. 58. 
voted several illuminating critical studies to the offensive of these active minorities belonging to the indigenist-decolonial movement, who, under the guise of anti-racism, work to racialize the cultural sphere. ${ }^{71}$

The new political-intellectual extreme left is seduced by the hypercriticism of the European heritage and advocates a cultural and cognitive hyper-relativism, which postulates that all forms of life and all forms of thought are equal. By advocating "epistemic disobedience," the advocates of postcolonial or decolonial thought are engaged in a process of destruction of the foundations of scientific thought and democratic politics. We are witnessing the emergence of a new, paradoxical, and perverse form of racial worldview, which is advancing under the guise of anti-racism. And, at the same time, we are witnessing the trivialization of an anti-white racism that, if not clearly assumed, is inscribed in the vocabulary, reasoning, and explanations of the promoters of postcolonialism, subalternism, and decolonialism. Let us point out the Manichaean opposition and the crude hierarchy of values found in their writings: the "white" racial identity is on the side of Evil, i.e., the damned dominant; other racial identities, not "white," are on the side of Good, i.e., the dominated, the saints "damned of the earth." From this perspective, personal identity is first of all a racial identity. But not all racial identities are the same. The hierarchization and opposition of racially based collective identities drive away the concern for equality "without distinction of," which is the basis for a coherent anti-racism. Decolonial and racialist identitarianism covers itself with the clothes of an anti-racism utterly foreign to it and masks a total hostility to "whites." Anti-white racism does exist, unfortunately. Starting with those who fiercely deny its existence. They hide behind their little finger.

In France, by its increasing spread outside the circle of cultivated urban elites, postcolonialism and its explicitly politicized version, decolonialism, risk dragging all left-wing families into adherence to a vision of identity that can only divide and oppose citizens. By accustoming the latter to "see the issues of the day principally through the lens of identities"72 and to frame them in ethno-racial terms ("whites" vs. others) - as they have done in the United States since the 1980s - the promoters of post-

71. Isabelle Barbéris, "La racialisation de la culture: Institutionnalisation de l'indigénisme au cœur de la République des arts," Cités 75, no. 3 (2018): 95-108; Barbéris, L'art du politiquement correct (Paris: PUF, 2019).

72. Mark Lilla, The Once and Future Liberal: After Identity Politics (New York: HarperCollins, 2017), pp. 1-17. 
colonialism are attacking the founding values and norms of the French republican tradition.

We are witnessing a reinvention of the racial vision of historical and social issues through contemporary pseudo anti-racist sophistry. Let us start from the premise that "race explains everything." This statement can be interpreted in two ways and, therefore, be translated into two versions: (1) a biologizing and essentialist version, with "race" defined as an anthropo-biological fact; (2) a culturalizing and constructivist version, with "race" defined as a social-historical construction. But these two versions, the racist and the pseudo anti-racist, are cognitively the same: they imply a racialization of the explanatory models. Behind the cloud of academic smoke that surrounds postcolonial studies, one must discern an enterprise of trivialization of racialist representations, beliefs, and modes of explanation. 
Timely. Provocative. Independent.

Telos is a must-read for anyone with a serious interest in politics, philosophy, culture, and the arts. Subscribe now at www.telospress.com.
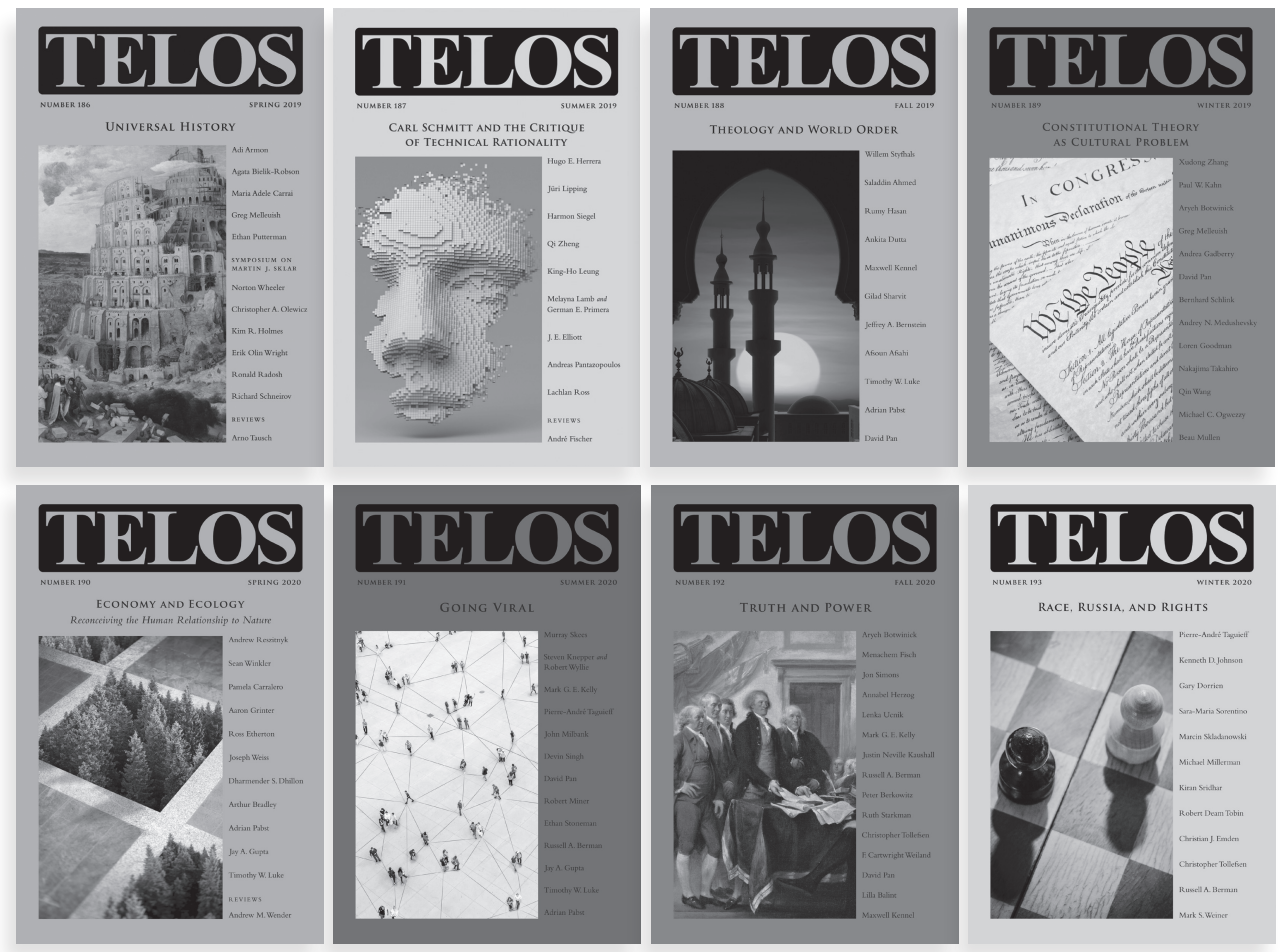

Since 1968, the quarterly journal Telos has served as the definitive international forum for discussions of political, social, and cultural change. Readers from around the globe turn to Telos to engage with the sharpest minds in politics and philosophy, and to discover emerging theoretical analyses of the pivotal issues of the day.

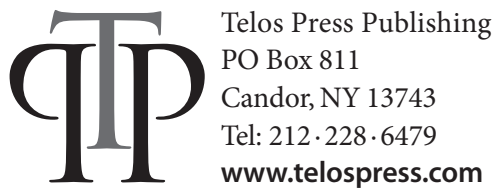

